\title{
FIGQY phosphorylation defines discrete populations of $L 1$ cell adhesion molecules at sites of cell-cell contact and in migrating neurons
}

\author{
Scott M. Jenkins ${ }^{1, \star}$, Krishnakumar Kizhatil ${ }^{1}$, Neal R. Kramarcy ${ }^{2}$, Anindita Sen ${ }^{1}$, Robert Sealock ${ }^{2}$ and \\ Vann Bennett ${ }^{1}$ \\ ${ }^{1}$ Howard Hughes Medical Institute and Departments of Biochemistry and Cell Biology, Duke University Medical Center, Durham, NC 27710, USA \\ 2Department of Cell and Molecular Physiology, University of North Carolina, Chapel Hill, NC 27599, USA \\ *Author for correspondence (e-mail: s.jenkins@cellbio.duke.edu)
}

Accepted 24 July 2001

Journal of Cell Science 114, 3823-3835 (2001) (C) The Company of Biologists Ltd

\section{SUMMARY}

Phosphorylation of neurofascin, a member of the L1 family of cell adhesion molecules (L1 CAMs), at the conserved FIGQY-tyrosine abolishes the ankyrin-neurofascin interaction. This study provides the first evidence, in Drosophila melanogaster and vertebrates, for the physiological occurrence of FIGQY phosphorylation in L1 family members. FIGQY tyrosine phosphorylation is localized at specialized cell junctions, including paranodes of sciatic nerve, neuromuscular junctions of adult rats and Drosophila embryos, epidermal muscle attachment sites of Drosophila, and adherens junctions of developing epithelial cells of rat and Drosophila. In addition, FIGQYphosphorylated L1 CAMs are abundantly expressed in regions of neuronal migration and axon extension, including the embryonic cortex, the neonatal cerebellum and the rostral migratory stream, a region of continued neurogenesis and migration throughout adulthood in the rat. Based on our results, physiological FIGQY-tyrosine phosphorylation of the $\mathrm{L} 1$ family likely regulates adhesion molecule-ankyrin interactions establishing ankyrin-free and ankyrin-containing microdomains and participates in an ankyrin-independent intracellular signaling pathway at specialized sites of intercellular contact in epithelial and nervous tissue.

Key words: Neurofascin, Ankyrin, Neuroglian, Neuronal migration, Nodes of Ranvier, Neuromuscular junction, Adherens junction

\section{INTRODUCTION}

Cell adhesion and signal transduction are intertwined in cell functioning. Involvement of cell adhesion molecules (CAMs) in signaling cascades has become accepted for all the major families of CAMs, including integrins, cadherins and Ig CAMs (Walsh and Doherty, 1997; Jones et al., 1999; Behrens, 1999). Support for the participation of cell adhesion molecules in intracellular signaling is based largely on experiments performed in vitro and in cell culture. However, functionally important signaling events in metazoans occur in the complex environment of multicellular organisms. Detailed understanding of pathways that integrate cell adhesion and signaling will ultimately require knowledge of the specific amino acid residue(s) subject to phosphorylation, as well as the precise cellular localization of the relevant regulatory signals, protein kinases, protein phosphatases and adapter proteins. A necessary first step in elucidating a physiologically relevant pathway would be to determine, at high resolution in tissues of an intact organism, the cellular localization of cell adhesion molecules phosphorylated at specific amino acid residues. Surprisingly, little information at this physiological level is currently available for the major classes of cell adhesion molecules.

This study takes that necessary first step by addressing the physiological localization of the L1 family of cell adhesion molecules phosphorylated at a highly conserved tyrosine residue located in the cytoplasmic domain within the ankyrinbinding site (Garver et al., 1997). To our knowledge, this study and that of Chen et al. (Chen et al., 2001) are the first to address the physiological occurrence of a specific, functionally important phosphorylation event in a major family of cell adhesion molecules. The L1 family comprises L1, neurofascin, NrCAM, NgCAM and CHL-1 in vertebrates, and neuroglian and LAD-1 in Drosophila and Caenorhabditis elegans, respectively (Bieber et al., 1989; Hortsch, 1996; Chen et al., 2001). Subsequently, the term L1 CAMs will be used to describe vertebrate family members and L1-type will be used to include both vertebrate and invertebrate L1 family members.

L1-type adhesion molecules are comprised of variable extracellular domains made up of immunoglobulin and fibronectin type III repeats, which can contribute to both homophilic and heterophilic binding, and a relatively conserved cytoplasmic domain that associates with ankyrin (Davis et al., 1993; Hortsch, 2000). The clinical importance of L1 CAMs is evident from mutations in L1 itself which result in mental retardation and hydrocephalus (Fransen et al., 1997; Kamiguchi et al., 1998; Kenwrick et al., 2000). The L1-type adhesion molecules have been implicated in processes important for nervous system development including axon guidance (Stoeckli and Landmesser, 1995; Cohen et al., 1998), neuronal process extension (Seilheimer, and Schachner, 1988; 
Demyanenko et al., 1999), cell migration (Lindner et al., 1983) and axon fasciculation (Lemmon and McLoon, 1986; Rathjen et al., 1987; Honig et al., 1998). L1 CAMs are also likely involved in the formation and/or functioning of nodes of Ranvier because a $186 \mathrm{kDa}$ neurofascin isoform and $\mathrm{NrCAM}$ are enriched in the axon nodal segment of adult and developing myelinated axons (Davis et al., 1996; Lambert et al., 1997; Tait et al., 2000). Moreover, a $155 \mathrm{kDa}$ neurofascin isoform is a component of the paranodal loops of Schwann cells and may contribute to axo-glial contacts (Tait et al., 2000).

In addition to their prominent localization in the nervous system, NrCAM and L1 have been identified in multiple nonneuronal tissues including pancreas, placenta, adrenal glands and cells of the immune system (Kadmon et al., 1998; Wang et al., 1998). L1 is also expressed in a variety of epithelial tissues including the epidermis, lung, small intestine and colon (Nolte et al., 1999). Neuroglian, the Drosophila L1 ortholog, is expressed in hindgut, muscle, trachea and salivary glands in addition to the nervous system (Hortsch et al., 1990). LAD-1, the $C$. elegans L1 CAM, is expressed ubiquitously at sites of cell-cell contact beginning at the two cell stage (Chen et al., 2001). Although these findings suggest the fundamental importance of L1-type adhesion molecules outside the nervous system, little work has emphasized their non-neuronal roles.

L1-type adhesion molecules have been implicated in a variety of signal transduction pathways. Potential protein kinases interacting directly or indirectly with this family include Src (Ignelzi et al., 1994), the Eph kinase Cek5 (Zisch et al., 1997), the fibroblast growth factor receptor (FGFR) (Saffell et al., 1997; Garcia-Alonso et al., 2000; Chen et al., 2001), and the mitogen-activated protein kinase (MAPK) (Schmid et al., 2000; Schaefer et al., 1999). Nerve growth factor and fibroblast growth factor both promote phosphorylation of neurofascin in cultured neuroblastoma cells at a site identified as the conserved FIGQY tyrosine residue in the ankyrin-binding motif (Garver et al., 1997, Tuvia et al., 1997). Phosphorylation of the FIGQY-tyrosine abolishes ankyrin binding and neurofascin-mediated cell segregation (Garver et al., 1997; Tuvia et al., 1997). The FIGQY/H mutation in human L1 results in clinical disease, suggesting a critical role of the FIGQY-tyrosine in either ankyrin-binding and/or signaling (Fransen et al., 1998). Additionally, FIGQY tyrosine phosphorylation in $C$. elegans has been hypothesized to be involved in maintenance of tissue integrity during mechanical stress, based on its localization at intercellular junctions in epithelial tissues that experience mechanical strain (Chen et al., 2001).

This study demonstrates that phosphorylation of the FIGQY tyrosine of L1-type adhesion molecules occurs in neuronal and non-neuronal tissues of the rat and Drosophila using an antibody specific for the phospho-FIGQY tyrosine. FIGQYphosphorylated L1-type adhesion molecules are localized by immunofluorescence at sites of cell-cell contact in nervous system and in epithelial tissues. These results, and those of Chen et al. (Chen et al., 2001) describing the localization of FIGQY-phosphorylated LAD-1 in C. elegans, suggest the presence of a novel signaling pathway that is important for regulating L1-type adhesion molecule function in multiple developmental stages and anatomical locations, and that is conserved among family members.

\section{MATERIALS AND METHODS}

\section{SDS-PAGE and Immunoblotting}

SDS-PAGE and immunoblot analysis using ${ }^{125}$ I-labeled protein A and autoradiography were performed as described (Garver et al., 1997; Lambert et al., 1997). Some immunoblots (immunoprecipitates and ovalbumin-coupled peptides) were developed using enhanced chemiluminesence (ECL) (Amersham). Brain tissue for immunoblotting was homogenized in four volumes of ice-cold homogenzation buffer (10 mM phosphate buffer ( $\mathrm{pH}$ 7.3) containing $0.32 \mathrm{M}$ sucrose, $10 \mathrm{mM}$ sodium fluoride, $1.0 \mathrm{mM}$ EDTA, $1.0 \mathrm{mM}$ AEBSF, $10 \mu \mathrm{g} / \mathrm{ml}$ leupeptin, and $1.0 \mathrm{mM}$ vanadate). Homogenates were immediately added to $5 \times$ PAGE buffer $(50 \mathrm{mM}$ Tris, $\mathrm{pH} 8.0$, $5.0 \%$ SDS, 25\% sucrose, 5.0 mM EDTA, $200 \mathrm{mM}$ DTT, Bromophenol Blue), and boiled for 5 minutes. For immunoprecipitation of L1 CAMs, embryonic and neonatal brains were homogenized in ice-cold modified RIPA buffer (50 mM Tris ( $\mathrm{pH} 7.5$ ), $150 \mathrm{mM} \mathrm{NaCl}, 0.5 \%$ sodium deoxycholate, $0.5 \% \mathrm{NP}-40,1.0 \mathrm{mM}$ benzamidine, $1.0 \mathrm{mM}$ EDTA, $20 \mathrm{mM} \mathrm{NaF}, 1.0 \mathrm{mM} \mathrm{Na} \mathrm{VO}_{4}, 1.0 \mathrm{mM}$ PMSF, $1.0 \mathrm{mM}$ AEBSF and $10 \mu \mathrm{g} / \mathrm{ml}$ leupeptin). Homogenates were centrifuged to pellet particulate material and the supernatants were incubated overnight at $4{ }^{\circ} \mathrm{C}$ with the indicated antibody. Immune complexes were precipitated with protein A sepharose beads.

\section{Cell culture and transfection}

B104 rat neuroblastoma cells plated at $1-3 \times 10^{5}$ cells per $35 \mathrm{~mm}$ plate were cultured in Dulbecco's Modified Eagle's Medium (Gibco) containing $1.0 \%$ fetal bovine serum (HyClone), $2.0 \mathrm{mM}$ glutamine (Gibco), and $1.0 \%$ Pen-Strep (Gibco). Cells were transfected with either HA-tagged wild-type neurofascin or FIGQY to $\mathbf{F}$ mutant neurofascin using Lipofectamine (Gibco). Thirty-six hours after transfection, cells were switched to serum-free medium and incubated overnight before being treated with $50 \mathrm{ng} / \mathrm{ml}$ basic FGF for 45 minutes. Cells were harvested in $50 \mathrm{mM}$ Tris $\mathrm{Cl}(\mathrm{pH} 7.5), 0.5 \%$ deoxycholate, $1.0 \%$ NP40, 1.0\% TritonX-100, 1.0 mM EDTA, PMSF $(200 \mu \mathrm{g} / \mathrm{ml})$, AEBSF $(2 \mathrm{mM})$, leupeptin and pepstatin $(10 \mu \mathrm{g} / \mathrm{ml})$, dephostatin $(50 \mu \mathrm{M})$, sodium vanadate $(1.0 \mathrm{mM})$ and sodium fluoride (1.0 mM). FIGQY to $\mathbf{F}$ mutant neurofascin was made using the QuickChange site-directed mutagenesis kit (Stratagene) as described (Zhang et al., 1998).

\section{Immunocytochemistry}

Perfusion of adult rats with $2.0 \%$ paraformaldehyde and immunocytochemistry with frozen sections of rat brain, sciatic nerve and whole embryos were performed as described (Kordeli et al., 1990; Davis et al., 1996). Neuromuscular junction preparation and immunofluorescence were performed as described (Kramarcy and Sealock, 2000). For phosphatase treatment of embryonic (E17) brain sections, sections were incubated at $30^{\circ} \mathrm{C}$ for 3 hours with 3.3 units $/ \mu l$ of the protein tyrosine phosphatase YOP (New England Biolabs) (approximately $60 \mathrm{U}$ of phosphatase per tissue section) in the buffer supplied by the manufacturer. Sections were then processed for immunofluorescence.

Antibodies used include a polyclonal antibody against the cytoplasmic domain of neurofascin (Davis et al., 1993), a polyclonal antibody against NrCAM (Davis et al., 1996), a polyclonal antibody against L1 (a gift from Dr C. Lagenaur) (Chung et al., 1991), a monoclonal antibody (1B7) that recognizes both isoforms of neuroglian (a gift from Dr M. Hortsch) (Bieber et al., 1989), a monoclonal antibody against FasII (a gift from Dr C. Goodman) (Seeger et al., 1993; Van Vactor et al., 1993), a monoclonal antibody against PS alpha 2 (a gift from Dr J. Bloor) (Bogeart et al., 1987), a goat polyclonal antibody against horseradish peroxidase (ICN) (Desai et al., 1994), and a monoclonal antibody against a neuron-specific $\beta$ tubulin (TUJ1) (BabCO). Secondary antibodies used were goat antirabbit rhodamine and goat anti-mouse FITC, donkey anti-mouse FITC, donkey anti-rabbit TRITC and donkey anti-goat Cy5 (Jackson Labs). 


\section{Drosophila lines}

All Drosophila stocks were raised at $25^{\circ} \mathrm{C}$ on standard cornmeal/molasses/agar media. The following lines were used for this study: OregonR (wild type) and $\mathrm{nrg}^{\mathrm{l}} / \mathrm{FM} \mathrm{Fc}$ (neuroglian null mutant) (Leferve and Watkins, 1986, Hall and Bieber, 1997). Embryos were collected on apple juice agar plates $(0-16 \mathrm{H})$ and were dechorionated in $50 \%$ bleach for whole-mount preparations. The embryos were fixed in heptane saturated 4\% paraformaldehyde in PEM buffer $(100 \mathrm{mM}$ Pipes, $2 \mathrm{mM}$ NaEDTA and $1 \mathrm{mM}$ magnesium sulfate) for 30 minutes, devitellinized in methanol and washed in phosphate-buffered saline (PBS) containing $0.1 \% \mathrm{v} / \mathrm{v}$ Triton X-100 (PBT). Then the embryos were treated with 5\% Triton X-100 and 10\% horse serum in PBS for 1 hour and incubated with primary antibodies overnight at $4{ }^{\circ} \mathrm{C}$ with gentle rocking. Embryos were washed in PBT, incubated in PBT containing $10 \%$ horse serum, and incubated with the secondary antibodies for 3 hours at room temperature.

\section{Antibody generation and characterization}

Peptides that corresponded to the sequence surrounding FIGQY in rat neurofascin with the addition of a cysteine (Cys-Asn-Glu-Asp-GlySer-Phe-Ile-Gly-Gln-Tyr-Thr-Val-Arg-Lys-Asp) were synthesized in either their tyrosine phosphorylated or non-phosphorylated forms by the HHMI peptide synthesis facility at Duke University. Rabbits were immunized with the tyrosine phosphorylated peptides coupled, via the extra cysteine, to keyhole limpet hemocyanin (Pierce) as an immunogenic carrier molecule. An affinity-purified antibody specific for the phosphorylated FIGQY tyrosine (phospho-FIGQY antibody) was generated by depleting serum with the non-phosphorylated FIGQY peptide coupled to NHS-activated-agarose (Amersham Pharmacia Biotech). The flow-through from this non-phosphorylated peptide column was then purified using the phosphorylated FIGQY neurofascin peptide coupled to NHS-activated agarose. Antibody bound to the phosphorylated peptide was eluted with $4.0 \mathrm{M} \mathrm{MgCl}_{2}$, and dialyzed against PBS with glycerol, $1.0 \mathrm{mM}$ sodium azide and $1.0 \mathrm{mM}$ NaEDTA at $4^{\circ} \mathrm{C}$.

Immunoblots of brain extracts with this antibody revealed several bands, one of which was in the cytosolic fraction of embryonic and neonatal brain extracts, and migrated as a broad band around $350 \mathrm{kDa}$. Unlike the other bands recognized, this cytosolic band was not displaced by the immunizing peptide (data not shown). Two lines of evidence indicate that this cytosolic band did not contribute to any of the immunofluorescence seen with the antibody. First, immunofluorescence with the phospho-FIGQY antibody was displaced by the FIGQY-phosphorylated neurofascin peptide at all locations examined. Second, adsorbing the phospho-FIGQY antibody as described below to eliminate the cytosolic band from immunoblots had no effect on the pattern of immunofluorescence at any of the locations examined.

To eliminate this non-displaceable reactivity in immunoblots, cytosolic fractions (supernatants following centrifugation for 1 hour at $100,000 \mathrm{~g}$ ) of embryonic (E18) and neonatal (P10) rat brain were coupled to NHS-activated agarose. The phospho-FIGQY antibody was first adsorbed against the neonatal column followed by the embryonic column. These adsorption steps eliminated the cytosolic, non-displaceable band in the immunoblot but had no effect on the pattern of phospho-FIGQY immunofluorescence in any of the tissues examined. Therefore, for immunofluorescence, the adsorbed and nonadsorbed phospho-FIGQY antibodies are used interchangeably. An example comparing the immunofluorescent pattern of adsorbed phospho-FIGQY antibody to the non-adsorbed antibody is shown in Fig. 3.

The monoclonal antibody recognizing ankyrin $\mathrm{G}$ was generated against a unique peptide in the spectrin-binding domain and is commercially available from Zymed, Pharmingen and Biomol.

For initial characterization of the phospho-FIGQY antibody, peptides corresponding to the sequence surrounding FIGQY in rat neurofascin (see above), rat L1/NrCAM (Cys-Asn-Glu-Asp-Gly-Ser-
Phe-Ile-Gly-Gln-Tyr-Ser-Gly-Lys-Lys-Glu) and LAD-1 (Cys-ThrGlu-Asp-Gly-Ser-Phe-Ile-Gly-Gln-Tyr-Val-Pro-Gln-Lys-Ser) were synthesized in either their tyrosine phosphorylated or nonphosphorylated forms. Peptides were coupled to glutaraldehydeactivated turkey ovalbumin, electrophoresed and immunoblotted with the phospho-FIGQY antibody as indicated.

\section{RESULTS}

\section{L1 CAMs are phosphorylated at the FIGQY-tyrosine in mammals and Drosophila}

The goal of this study is to determine the cellular localization of FIGQY-phosphorylated L1-type adhesion molecules in a physiological context. To accomplish this we developed a polyclonal antibody capable of specifically recognizing, in immunoblots and immunofluorescence, the phospho-FIGQYtyrosine without crossreacting with other phospho-tyrosine proteins or with non-phosphorylated L1 CAM family members (see Materials and Methods). Several lines of evidence support the conclusion that the phospho-FIGQY polyclonal antibody specifically recognizes L1-type adhesion molecules phosphorylated at the FIGQY tyrosine (Fig. 1B-F). Antibody specificity was initially evaluated with ovalbumin-coupled peptides corresponding to the phosphorylated or nonphosphorylated FIGQY-containing sequences of rat neurofascin (nFIGQY), rat L1/NrCAM (LnFIGQY) or the relatively divergent LAD-1 of $C$. elegans (LdFIGQY) (compare Fig. 1B with $1 \mathrm{~A}$ for sequence comparison). Loading of equivalent amounts of protein in each lane was confirmed by Coomassie Blue staining (data not shown). The phospho-FIGQY polyclonal antibody did not recognize the non-phosphorylated form of any of the peptides, but did react strongly with the tyrosinephosphorylated nFIGQY peptide and, to a lesser extent, with the tyrosine-phosphorylated LnFIGQY and LdFIGQY peptides (Fig. 1B). Antibody phosphorylation specificity in immunofluorescence was evaluated by pretreating rat embryonic (E17) forebrain sections, which contain phospho-FIGQY reactivity (see also Fig. 7), with the tyrosine phosphatase YOP. Phosphatase treatment eliminated the phospho-FIGQY signal (Fig. 1C compare - with + ) indicating that the phospho-FIGQY antibody is phospho-tyrosine specific in immunofluorescence. Shown in Fig. 1C is the region from the marginal zone (MZ) to the top of the intermediate zone (see Fig. 7 for detailed description). Antibody specificity for the phosphorylated FIGQY tyrosine was addressed in B104 rat neuroblastoma cells transiently expressing either wild-type neurofascin (Y in Fig. 1D) or a FIGQY to F neurofascin mutant (F in Fig. 1D). Wild-type neurofascin in untreated cells (Fig. 1D, -) exhibited a low level of reactivity with the phospho-FIGQY antibody, while mutant neurofascin was not recognized at all. This residual reactivity against wild-type neurofascin is consistent with previous observations in B104 cells using a general phospho-tyrosine antibody (Garver et al., 1997) that tyrosine phosphorylation is not totally eliminated by serum starvation. Treatment of transfected B104 cells with basic fibroblast growth factor (bFGF) dramatically increased phospho-FIGQY polyclonal antibody reactivity with wild-type neurofascin but not with mutant neurofascin, demonstrating specificity of the antibody for the phosphorylated FIGQY tyrosine. The presence of transfected neurofascin in all samples was confirmed by a parallel 
A Neurofascin: NEDGSFIGQYTVRKD
L1/NrCAM: NEDGSFIGQYSGKKE
LAD-1: TEDGSFIGQYVPQKS
Nrg180: TEDGSFIGQYVPGKL
Nrg167: NEDGSFIGQYGRKGL

C

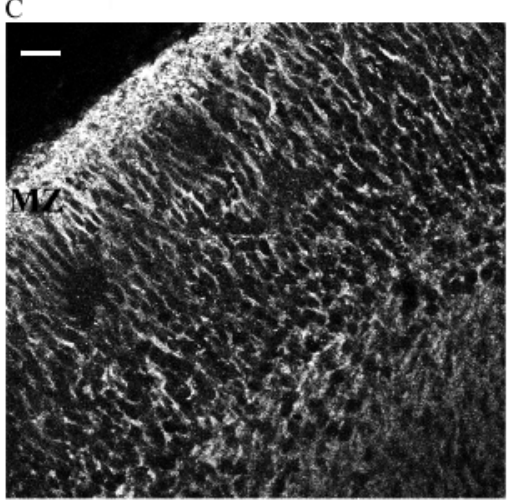

Phosphatase

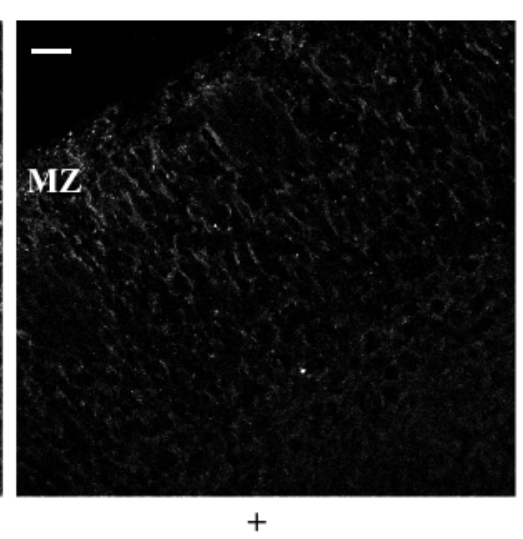

$+$

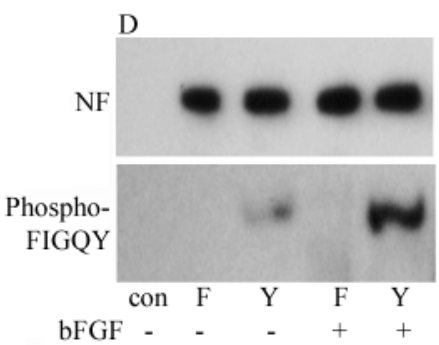

Fig. 1. The phospho-FIGQY polyclonal antibody is specific for FIGQYphosphorylated L1 CAMs. (A) Comparison of sequences surrounding the FIGQY tyrosine in neurofascin, $\mathrm{L} 1$ and $\mathrm{NrCAM}$, LAD-1 and neuroglian (long (nrg 180) and short (nrg167) forms). (B) Peptides corresponding to the sequences shown in A for either neurofascin (NF), L1 and $\mathrm{NrCAM}(\mathrm{L} 1 / \mathrm{Nr})$, or LAD-1 in their tyrosine phosphorylated (+) or nonphosphorylated (-) forms were coupled to turkey ovalbumin, electrophoresed and immunoblotted with the phospho-FIGQY polyclonal antibody. Each lane contains approximately $200 \mathrm{ng}$ of coupled peptide. (C) Sections of embryonic (E17) rat forebrain incubated in the presence (+) or absence (-) of the tyrosine phosphatase YOP and immunolabeled with the phospho-FIGQY polyclonal antibody. Scale bars: $25 \mu \mathrm{m}$. MZ stands for marginal zone. (D) B104 rat neuroblastoma cells

expressing either wild-type neurofascin (Y), neurofascin with the FIGQY tyrosine mutated to phenylalanine (F) or untransfected controls (con) were incubated in the presence $(+)$ or absence $(-)$ of bFGF. Extracts were immunoblotted with either a neurofascin-specific polyclonal antibody (top) or the phospho-FIGQY polyclonal antibody (bottom). (E) Extracts from either E17 rat brain or P6 cerebellum were immunoprecipitated with a polyclonal antibody against L1, neurofascin (NF) or with control IgG (labeled C). Immunoprecipitates were electrophoresed and immunoblotted with the phospho-FIGQY polyclonal antibody demonstrating that both L1 and neurofascin are phosphorylated at their FIGQY tyrosines. (F) Extracts from E17 embryonic brain (E), P10 neonatal brain (N), or adult brain (A) were electrophoresed and immunoblotted with the phospho-FIGQY polyclonal antibody, a previously characterized neurofascin antibody (NF), and an NrCAM antibody. The low molecular weight bands observed with the phospho-FIGQY polyclonal antibody in embryonic brain extract were also observed under control conditions (con) with only ${ }^{125} \mathrm{I}$-protein A and a control IgG at a similar exposure time. All immunoblots were developed using ${ }^{125} \mathrm{I}-$ protein A except for $(\mathrm{B}, \mathrm{E})$, which were developed using enhanced chemiluminescence.

immunoblot with a neurofascin-specific polyclonal antibody (Fig. 1D, top). L1 and neurofascin immunoprecipitated from either E17 rat brain or P8 cerebellum reacted with the phosphoFIGQY polyclonal antibody in immunoblots (Fig. 1E). Moreover, the phospho-FIGQY polyclonal antibody crossreacts with relatively few polypeptides in embryonic, neonatal and adult brain (Fig. 1F phospho-FIGQY) while in comparable samples a general phosphotyrosine antibody reacted with multiple polypeptides not recognized by the phospho-FIGQY polyclonal antibody (data not shown). Two of the major phospho-FIGQY- reactive polypeptides exhibited mobilities of 186 and $155 \mathrm{kDa}$ (Fig. 1F, phospho-FIGQY), which are similar to those of neurofascin. Approximately $70 \%$ of phospho-FIGQY antibody reactivity with brain polypeptides was displaced by low levels of the tyrosine phosphorylated nFIGQY peptide ( 1 mole peptide per mole $\mathrm{IgG}$ ) but no displacement was seen with an equal molar amount of a tyrosine phosphorylated LVDY peptide of equivalent length also derived from neurofascin or by a second unrelated tyrosine phosphorylated peptide corresponding to angiotensin II (S. M. J. and V. B., unpublished). The tyrosine phosphorylated 

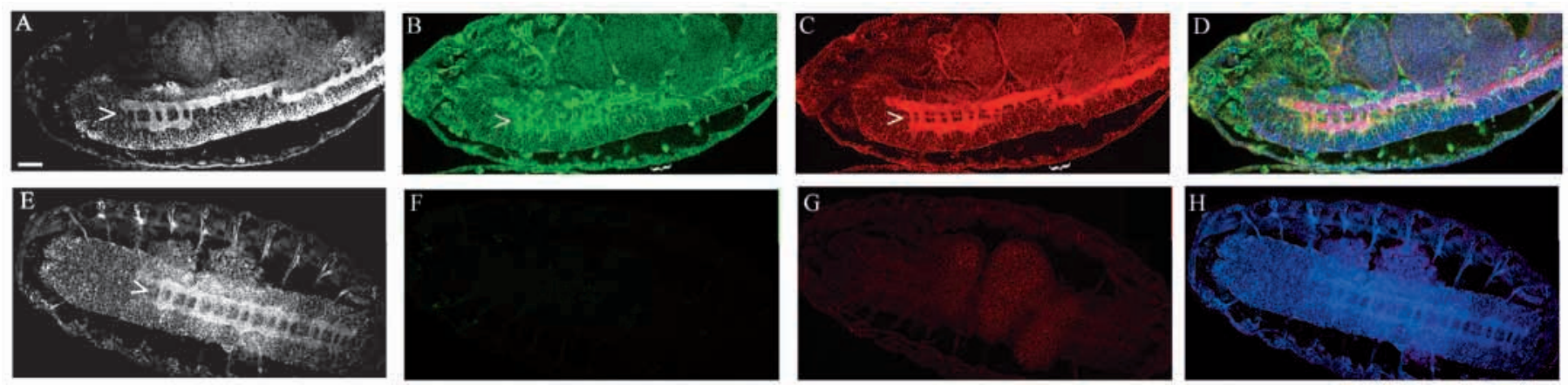

Fig. 2. The phospho-FIGQY polyclonal antibody labels developing nervous system and epithelia in neuroglian-expressing but not neurogliannull Drosophila embryos. Drosophila heterozygotes (A-D) or neuroglian null mutants (E-H), were examined by triple labeling immunofluorescence with anti-HRP as an antibody penetration control (A,E), anti-neuroglian to distinguish wild type from neuroglian null flies $(\mathrm{B}, \mathrm{F})$, and the phospho-FIGQY polyclonal antibody $(\mathrm{C}, \mathrm{G})$. Neuroglian nulls exhibited no phospho-FIGQY reactivity. Composite images are shown in $(\mathrm{D}, \mathrm{H})$ with HRP signal indicated in blue. Arrowheads mark the nervous system and brackets mark the epidermal epithelium. Scale bar: $25 \mu \mathrm{m}$.

nFIGQY peptide, but not the tyrosine phosphorylated angiotensin II peptide, also displaced immunofluorescent labeling with the phospho-FIGQY polyclonal antibody (for example, see Fig. 7).

The ideal control for antibody specificity would be an organism with null mutations that eliminated expression of all members of the L1 CAM family. Mice that lack all four L1 CAM family members are not available. However, Drosophila melanogaster express a single L1-type adhesion molecule, neuroglian, and a neuroglian null mutation that is embryonic lethal has been characterized (Bieber et al., 1989). The phospho-FIGQY polyclonal antibody recognizes neuroglian on immunoblots (data not shown). We examined reactivity of the phospho-FIGQY antibody in Drosophila embyros between developmental stages 12 and 15 that were either heterozygous (Fig. 2A-D) or homozygous (Fig. 2E-H) for the neuroglian null mutation. Neuroglian nulls can be distinguished from heterozygous embryos by the absence of neuroglian labeling (compare Fig. 2F with 2B). In triple labeled embryos, FIGQYphosphotyrosine immunoreactivity was present in the nervous system (Fig. 2C, arrowhead) and epidermal epithelium (Fig. $2 \mathrm{C}$, bracket) of heterozygous embryos but was conspicuously absent in neuroglian null embryos (Fig. 2G). Fig. 2A,E demonstrate labeling with an anti-HRP antibody as a control for antibody penetration into embryos with arrowheads indicating nervous system labeling. Composite images are shown in Fig. 2D,H. The lack of immunoreactivity in neuroglian null fly embryos provides striking confirmation of the specificity of the phospho-FIGQY polyclonal antibody for neuroglian. Pre-incubation of the phospho-FIGQY polyclonal antibody with tyrosine phosphorylated nFIGQY peptide eliminated the signal, while a comparable amount of the nonphosphorylated peptide did not (data not shown). The fact that signal is displaced with phospho- but not dephospho-FIGQY peptide provides further evidence that the antibody is specific for FIGQY-phosphorylated neuroglian.

The developmental expression of FIGQY tyrosine phosphorylation in the rat brain was examined in E17 embryos (labeled E in Fig. 1F), P10 neonates (labeled N in Fig. 1F) and adults (labeled A in Fig. 1F), where the amount of protein in each lane was matched based on initial brain mass. Embryonic and neonatal brain contained a phospho-FIGQY-reactive band of $186 \mathrm{kDa}$ and one at approximately $130 \mathrm{kDa}$ (phospho-
FIGQY, lanes E and N). The low molecular weight bands surrounding the $30 \mathrm{kDa}$ marker in embryonic brain extract represent reactivity of protein A itself, as they are present with control rabbit $\mathrm{IgG}$ and ${ }^{125}$ I-labeled protein $\mathrm{A}$ alone at comparable exposure time (Fig. 1F, Con). The $186 \mathrm{kDa}$ phospho-FIGQY-reactive band co-migrated with the $186 \mathrm{kDa}$ isoform of neurofascin (Davis et al., 1993) (Fig. 1F, compare phospho-FIGQY with NF), while the $130 \mathrm{kDa}$ phosphoFIGQY-reactive band did not correspond to either neurofascin or NrCAM. L1 of $130 \mathrm{kDa}$ has been reported (Liljelund et al., 1994), but does not contain the intracellular domain recognized by the phospho-FIGQY polyclonal antibody (Liljelund et al., 1994) and therefore is not responsible for the $130 \mathrm{kDa}$ band observed in embryonic and neonatal brain. CHL-1 has been reported to migrate at $125 \mathrm{kDa}$ (Holm et al., 1996). However, CHL-1 reactivity with the phospho-FIGQY polyclonal antibody remains to be evaluated directly as the CHL-1 sequence diverges in the FIGQY region (FIGAY for CHL-1).

Adult brain contained two major phospho-FIGQY-reactive bands co-migrating with major bands of $186 \mathrm{kDa}$ and $155 \mathrm{kDa}$ recognized by the neurofascin-specific antibody (Fig. 1F, compare lane A of phospho-FIGQY and NF) (Davis et al., 1993). Reactivity of the $186 \mathrm{kDa}$ phospho-FIGQY-reactive band in adult brain was approximately 1.7 times higher than that in neonatal brain and three times higher than in embryonic brain. However, when the level of neurofascin was equated in brain extract from embyros, neonates and adults, reactivity of this top band with the phospho-FIGQY polyclonal antibody was higher in embryo and neonatal brain than adult brain (data not shown). Pre-incubation of the phospho-FIGQY polyclonal antibody with a molar excess of the tyrosine phosphorylated nFIGQY peptide completely displaced these bands (data not shown).

\section{FIGQY-phosphorylated L1CAMs are localized at specialized sites of cell-cell contact at paranodes and the neuromuscular junction}

The finding that FIGQY-phosphorylation of neurofascin abolishes ankyrin-binding (Garver et al., 1997) suggests that ankyrin and FIGQY-phosphorylated L1-type adhesion molecules may be present at distinct sites. Ankyrin G exhibits a highly restricted localization within the nodal axon segment 

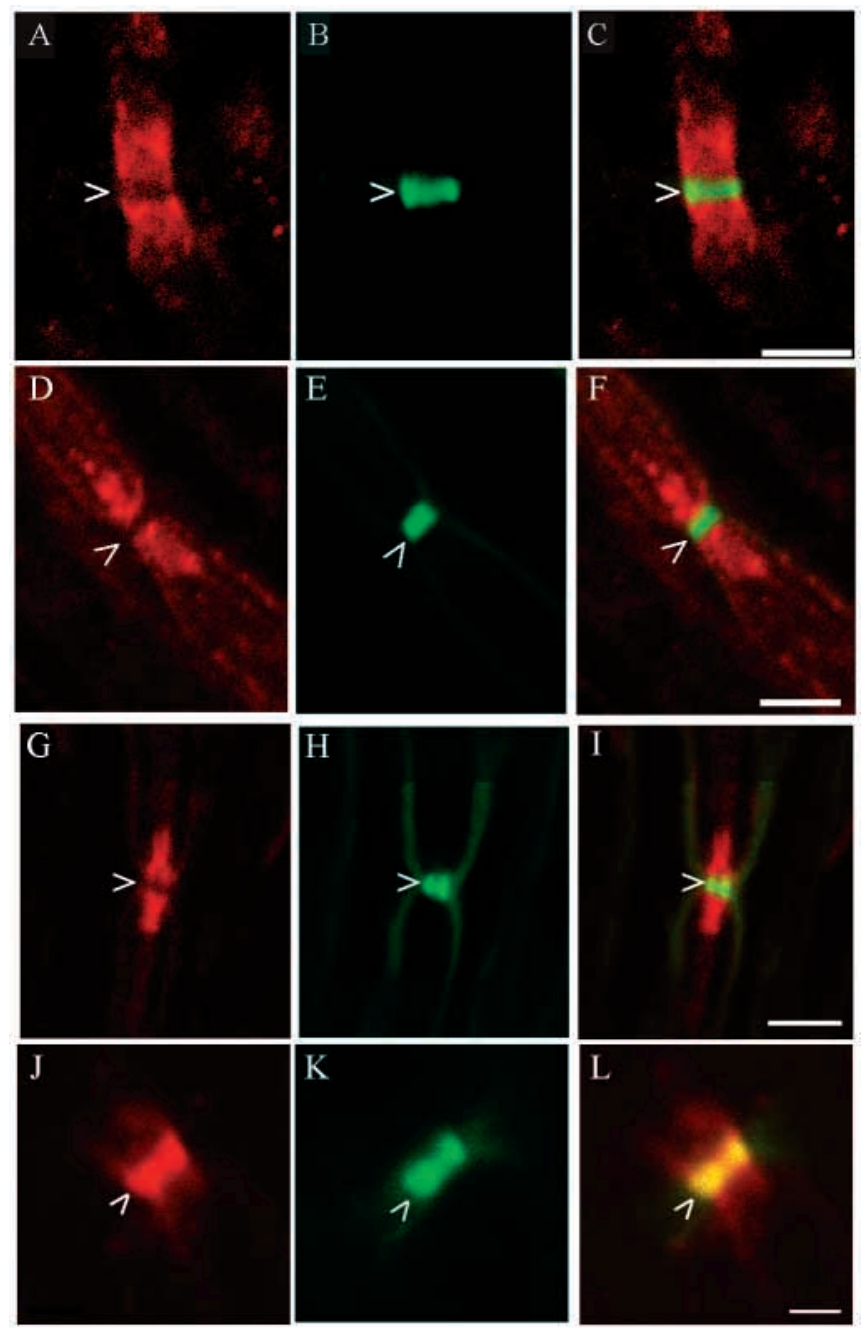

Fig. 3. FIGQY phosphorylation is concentrated in paranodal regions of adult sciatic nerve. Sections of adult rat sciatic nerve were labeled with either the phospho-FIGQY polyclonal antibody $(\mathrm{A}, \mathrm{D}, \mathrm{G})$ or a neurofascin-specific polyclonal antibody $(\mathrm{J})$. Nodes of Ranvier were visualized with the monoclonal antibody against ankyrin $\mathrm{G}$ (B,E,H,K). Composite images (C,F,I) demonstrate the minimal overlap between nodal ankyrin $\mathrm{G}$ (green) and paranodal phosphoFIGQY (red). The neurofascin-specific polyclonal antibody recognizes both nodes and paranodes (J-L). The phospho-FIGQY polyclonal antibody in $\mathrm{G}$ was cytosol cleared, demonstrating no difference in the pattern of immunofluorescence with cytosol clearing (see Materials and Methods for details). White arrowheads indicate the location of nodes of Ranvier. Scale bars: $5 \mu \mathrm{m}$ in A-I; $2.5 \mu \mathrm{m}$ in J-L.

of nodes of Ranvier of myelinated nerves (Kordeli et al., 1995), while neurofascin is present in both the nodal axon segment and the paranodal loops of Schwann cells where they contact the axon (Davis et al., 1996; Tait et al., 2000). Ankyrin G also is confined within a specialized subdomain of the neuromuscular junction, where it is colocalized in the junctional folds with voltage-gated $\mathrm{Na}^{+}$channels in a location distinct from the acetylcholine (ACh) receptors, which are in receptor rich zones adjacent to the presynaptic terminal (Flucher and Daniels, 1989; Wood and Slater, 1998; Kordeli et al., 1998). Although L1 CAMs have not yet been identified at mammalian neuromuscular junctions, neuroglian is present at the developing neuromuscular junction of fly embryos (Fig. 5). We therefore examined nodes of Ranvier of rat sciatic nerve and the neuromuscular junction of rat and Drosophila for the presence of FIGQY-phosphorylated L1CAMs.

Nodes of Ranvier exhibit a prominent paranodal distribution of a FIGQY-phosphorylated L1 CAM and reduced or absent FIGQY-phosphotyrosine labeling at the nodal axon segment, which is marked by staining with the antibody against ankyrin$\mathrm{G}$ (Fig. 3). Composite images (3C, F and I) reveal a striking segregation of ankyrin $\mathrm{G}$ (green) from phospho-FIGQY label (red). By contrast, total neurofascin, as revealed by a neurofascin-specific polyclonal antibody (Davis et al., 1993), is found in both the node of Ranvier and the paranodes (Fig. 3J-L). The majority of total neurofascin is found at the node making the paranodal phospho-FIGQY signal more remarkable. The phospho-FIGQY polyclonal antibody also labeled longitudinally oriented structures in the sciatic nerve that likely correspond to unmyelinated axons, as described previously (Davis et al., 1996) (data not shown). A similar paranodal distribution of phospho-FIGQY was observed with the cytosol-adsorbed phospho-FIGQY polyclonal antibody (Fig. 3G-I) (see Materials and Methods for description of cytosol-adsorption). Paranodal phospho-FIGQY labeling was displaced by pre-incubating the antibody with the tyrosine phosphorylated nFIGQY peptide (data not shown, see Fig. 7 for an example of peptide displacement).

We also observed FIGQY-phosphotyrosine label postsynaptically at the adult rat neuromuscular junction. Fig. 4 shows thin sections of adult neuromuscular junction labeled with $\alpha$-bungarotoxin, to visualize $\mathrm{ACh}$ receptors (Fig. 4A,D), and either the ankyrin-G monoclonal antibody (Fig. 4B) or the phospho-FIGQY polyclonal antibody (Fig. 4E). PhosphoFIGQY label co-localizes with the ACh receptors at the crests of junctional folds (Fig. 4F), while ankyrin $\mathrm{G}$ is localized exclusively to the deep regions of junctional folds and does not overlap with ACh receptor expression (Fig. 4C). Several regions of punctate phospho-FIGQY labeling are visible. No phospho-FIGQY labeling is seen in the junctional folds. Phospho-FIGQY labeling was eliminated by pre-incubating the antibody with the tyrosine phosphorylated nFIGQY peptide (data not shown). Antibodies against neurofascin, $\mathrm{NrCAM}$ and L1 failed to label the neuromuscular junction postsynaptically in a pattern similar to the phospho-FIGQY polyclonal antibody (data not shown). The L1 polyclonal antibody labeled presynaptic structures at the neuromuscular junction (data not shown). These results suggest that the L1 CAM present at the neuromuscular junction either is distinct from neurofascin, L1 and $\mathrm{NrCAM}$, or that it represents a splice form not recognized by our antibodies.

FIGQY-phosphorylated neuroglian localizes to the developing neuromuscular junction of Drosophila embryos at stage 16/17 (Fig. 5A-C, white arrowheads), as indicated by overlap with the junctional marker fasciclin II (Fas II) (Schuster et al., 1996) (Fig. 5C, white arrowhead). We were unable to distinguish presynaptic from postsynaptic sites in Drosophila embryos. The presence of neuroglian at the neuromuscular junction was confirmed by double labeling with the antineuroglian antibody 1B7 (Bieber et al., 1989) (Fig. 5D, white arrowhead) and the phospho-FIGQY polyclonal antibody (white arrowheads in Fig. 5E,5F for overlap). At this stage, the presynaptic terminal has contacted the muscle but has not yet 

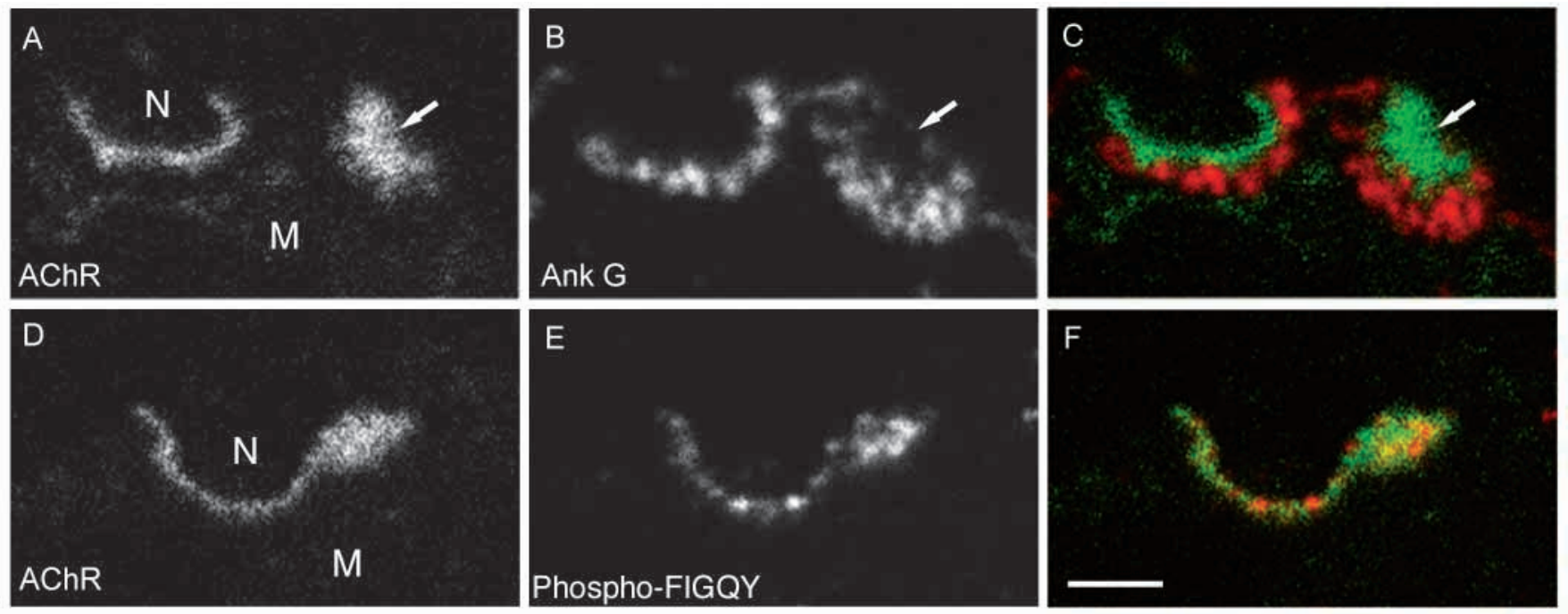

Fig. 4. FIGQY-phosphorylation occurs at the vertebrate neuromuscular junction. ACh receptors at the rat neuromuscular junction as labeled by bungarotoxin $(A, D)$ are confined to the crests of junctional folds while ankyrin $G(B)$ is confined to the deep regions of these folds in muscle cell plasma membrane. The two distributions do not overlap (C, arrows indicate identical position in all three images). FIGQY-phosphorylation (E) is strictly confined to the crests of junctional folds with ACh receptors (D) but has a more punctate distribution than ACh receptors.

Composite images are shown in C,F. Scale bar: $2 \mu \mathrm{m}$. N, location of nerve terminals; M, muscle cell.

formed the varicosities that develop into the characteristic synaptic boutons of the larval neuromuscular junction (Broadie, 1999). FIGQY phosphorylation was no longer evident in the larval neuromuscular junction (data not shown), indicating the developmental nature of this phosphorylation event in Drosophila and suggesting that the specific function of FIGQY phosphorylation at the neuromuscular junction is different in Drosophila and vertebrates.

In addition to this junctional staining, some phospho-FIGQY labeling did not overlap with Fas II (yellow arrowheads in 5). These structures correspond to sites of muscle-tendon cell attachment, which are epidermal muscle attachment sites
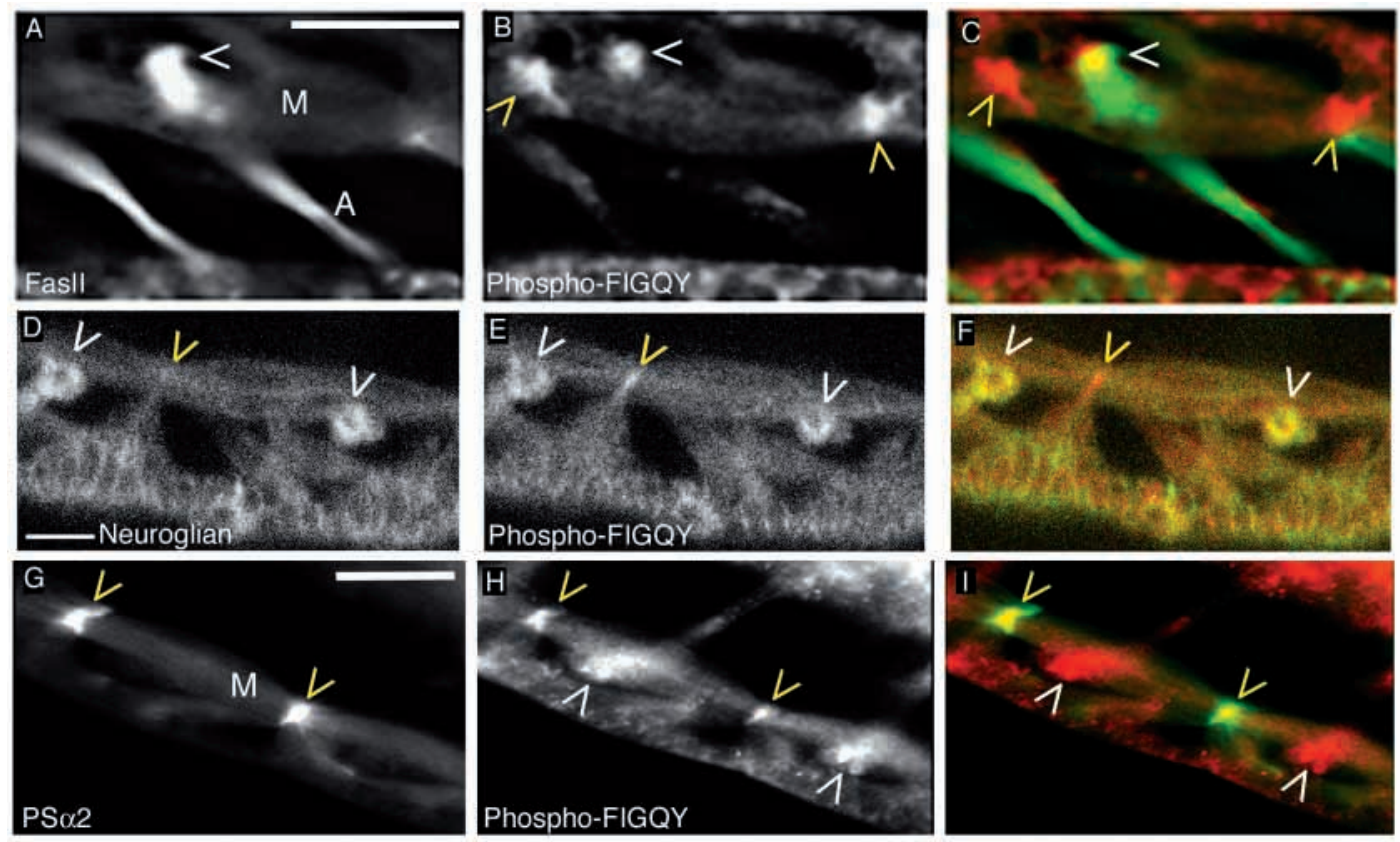

Fig. 5. FIGQY phosphorylated neuroglian is present at the developing neuromuscular junction and at sites of muscle-tendon attachment in Drosophila embryos. (A) The developing neuromuscular junction of Drosophila embryos is shown as marked by Fas II labeling (white arrowhead). FIGQY-phosphorylated neuroglian is present at the neuromuscular junction (B, C for composite). (D-F) Embryos were labeled with an anti neuroglian antibody (D) and the phospho-FIGQY polyclonal antibody (E). A composite image is shown in F, with the developing neuromuscular junction marked by a white arrowhead. The phospho-FIGQY polyclonal antibody also labels muscle-tendon attachment sites (B-I, yellow arrowheads) as indicated by overlap with PS $\alpha 2(\mathrm{G})$ (yellow arrowheads). Composite image shown in (L). Neuroglian is also present at these sites (D-F, yellow arrowheads) although it is not dramatically enriched. Scale bars: $10 \mu \mathrm{m}$. A, axon of presynaptic nerve cell; $\mathrm{M}$, muscle cell. 
(Tepass and Hartenstein, 1994), as indicated by their overlap with the position-specific integrin PS $\alpha 2$ (Fig. 5G-I, yellow arrowheads) (Martin-Bermudo and Brown, 1996). While neuroglian is present at these attachment sites (Fig. 5D-F, yellow arrowheads), it is not much enriched suggesting that the neuroglian that is present is highly FIGQY-phosphorylated. The phospho-FIGQY signal was displaced by pre-incubation of the antibody with phosphorylated nFIGQY peptide (data not shown).

\section{FIGQY-phosphorylated L1-type adhesion molecules are concentrated in adherens junctions of epithelial cells}

Neuroglian expression occurs in multiple epithelial tissues of Drosophila (Bieber et al., 1989; Hortsch et al., 1990). We therefore examined epithelial tissues of wildtype embryos between stages 12 and 15 for FIGQY-phosphorylated neuroglian (Fig. 6). Neuroglian (phosphorylated plus dephorylated forms) is localized along the basolateral domains of epithelial cells of the hindgut (Fig. 6B) while FIGQY-phosphotyrosine label is highly enriched in an apicolateral domain (Fig. 6A) identified as adherens junctions by colocalization with the adherens junction marker armadillo/ $\beta$-catenin (Fig. 6E) (Cox et al., 1996). The merged image in Fig. 6F demonstrates the striking overlap between FIGQYphosphorylated neuroglian and armadillo (areas of overlap in yellow) at adherens junctions. Some FIGQY-phosphorylated neuroglian is also present at the interface between gut epithelium basolateral membranes and visceral muscle , and probably corresponds to hemi-adherens junctions based on location (Tepass and Hartenstein, 1994) (Fig. 6A).

FIGQY-phosphotyrosine label also is concentrated in adherens junctions of embryonic rat lung epithelium (Fig. 6G). A higher magnification image of the boxed region in Fig. 6G is shown in Fig. 6H. Antibodies against L1 and NrCAM did not label lung epithelium although some signal was observed with a neurofascin-specific antibody (data not shown). Adult lung epithelium did not contain FIGQY-phosphotyrosine label, indicating the developmental nature of this phosphorylation event (data not shown). FIGQYphosphotyrosine label also was concentrated in apical regions of the E15 rat midgut, although it was not possible to resolve adherens junctions in these sections (Fig. 6I). A similar distribution of NrCAM is demonstrated in Fig. 6J, suggesting that NrCAM may be phosphorylated at the FIGQY tyrosine in this tissue. L1 did not exhibit a similar distribution (data not shown). The phospho-FIGQY polyclonal antibody signal in the gut and lung was completely displaced by pre-incubation with the tyrosinephosphorylated nFIGQY peptide (data not shown).

\section{FIGQY-phosphorylated L1 CAMs are present in regions of the central nervous system enriched in motile cells}

Extensive neuronal migration and axon extension occur in the late embryonic rat forebrain (Hatten, 1999; Bar et al., 2000). Neuroblasts are generated in the ventricular zone and then migrate outward and settle in an inside-out manner to produce the layered structure of the mature cortex. The phospho-FIGQY polyclonal antibody labels cells lining the lateral ventricle (LV), in the intermediate zone (IZ) and in the marginal zone (MZ) in the embryonic day 17 rat forebrain (Fig. 7A). Regions were defined as in Bar et al. (Bar et al., 2000). Distributions of both neurofascin (Fig. 7C) and L1 (Fig. 7D) are similar to that of FIGQY tyrosine phosphorylation (Fig. 7B) in the anterior intermediate zone of the developing cortex of an E18 rat embryo.
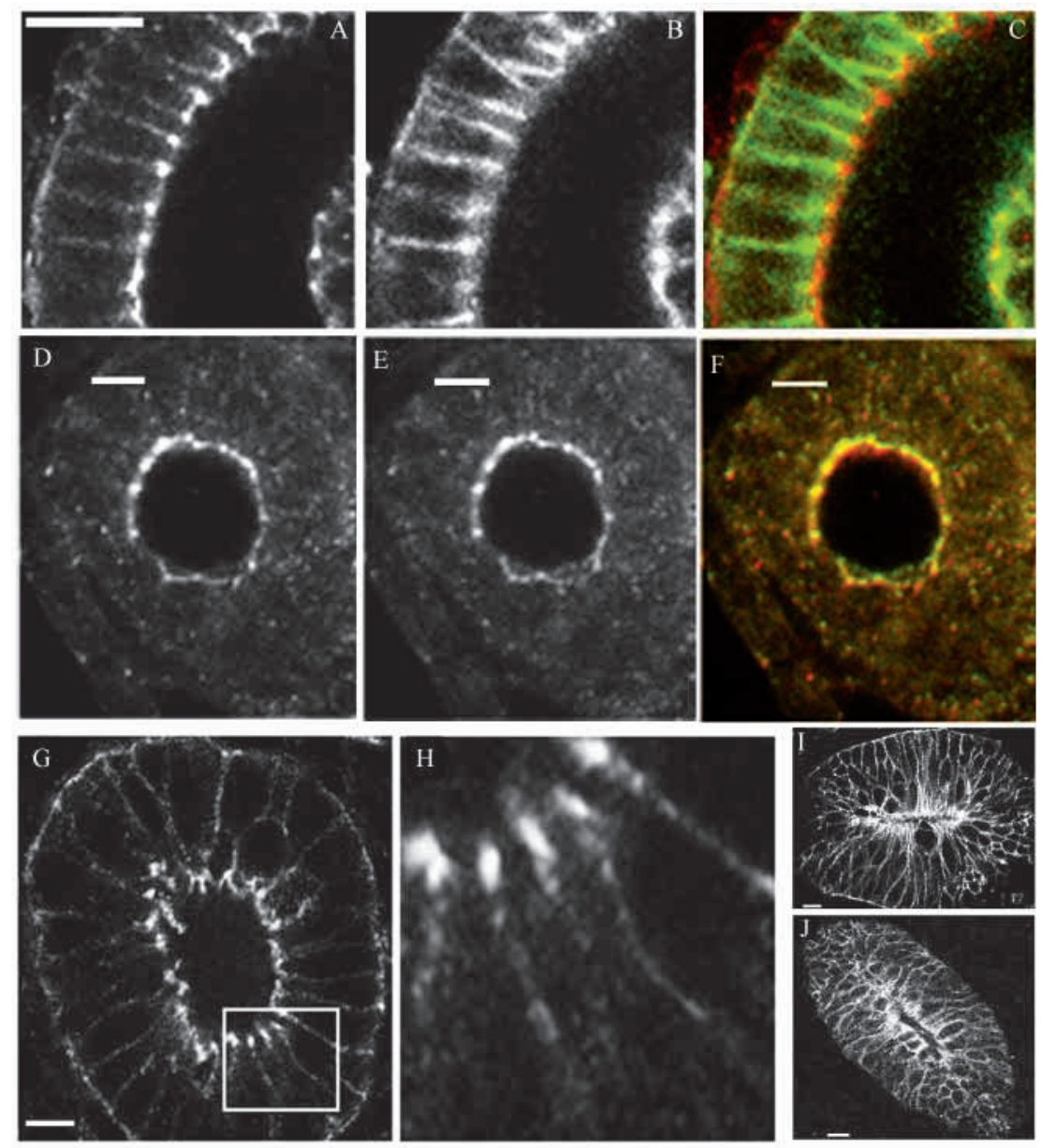

Fig. 6. FIGQY-phosphorylated L1 CAMs are localized to adherens junctions in vertebrate and Drosophila epithelial tissues. Drosophila embryos at stage 12-15 were labeled with a neuroglian antibody (B), demonstrating the presence of neuroglian in the basolateral domain of the hindgut. Labeling the same embryo with the phosphoFIGQY polyclonal antibody (A) revealed FIGQY-phosphorylated neuroglian concentrated in apicolateral regions. Composite image is shown in C. Embryos were also labeled with the adherens junction marker armadillo (E) and the phospho-FIGQY polyclonal antibody (D). A composite image is shown in F, with areas of overlap in yellow. (G) A section of E15 rat lung was labeled with the phospho-FIGQY polyclonal antibody demonstrating labeling at adherens junctions. A higher magnification image of the boxed area in $\mathrm{G}$ is shown in $\mathrm{H}$. (I) The phospho-FIGQY polyclonal antibody signal is concentrated apically in the developing midgut of the E15 rat. Adherens junctions could not be resolved in these sections. NrCAM shows a similar distribution $(\mathrm{J})$. Scale bars: $10 \mu \mathrm{m}$ in A-C,G,I,J; $5 \mu \mathrm{m}$ in D-F. 
Fig. 7. FIGQY tyrosine phosphorylation occurs in regions of neuroblast generation and migration and regions of axon extension. (A) A low magnification image of an E17 rat brain labeled with the phosphoFIGQY polyclonal antibody. The anterior region of developing cortex in E18 brain sections was labeled with the phosphoFIGQY polyclonal antibody (B), a neurofascin polyclonal antibody $(\mathrm{C})$ or an L1 polyclonal antibody (D) showing overlap between expression of these L1 CAMs and phospho-FIGQY. A similar pattern of phospho-FIGQY labeling in E15 embyros (E) was displaced when the phosphoFIGQY polyclonal antibody was preincubated in the presence of a fivefold molar excess of tyrosine phosphorylated nfFIGQY peptide $(\mathrm{F})$ but not in the presence of a fivefold molar excess of tyrosine phosphorylated AngII peptide (G). Sections of $\mathrm{P} 8$ cerebellum were labeled with the phospho-FIGQY polyclonal antibody $(\mathrm{H})$, a polyclonal antibody against neurofascin FNIII domains (I) or a polyclonal antibody against L1 (J) showing an overlapping distribution of phospho-FIGQY and L1 CAMs. (K-M) The presence of FIGQY phosphorylation in adult brain in neuroblasts migrating in the rostral migratory stream from the lateral ventricle to the olfactory bulb is shown. The phospho-FIGQY polyclonal antibody label partially overlaps with the early neuronal marker $\beta$ III tubulin in the subventricular zone (L) and (M) for overlap. CP, cortical plate; EGL, external germinal layer; IGL, internal granule cell layer; IZ, intermediate zone; LV, lateral ventricle; $\mathrm{ML}$, molecular layer;

$\mathrm{MZ}$, marginal zone; VZ, ventricular zone. Scale bars: $100 \mu \mathrm{m}$ in A; $25 \mu \mathrm{m}$ in B-M.
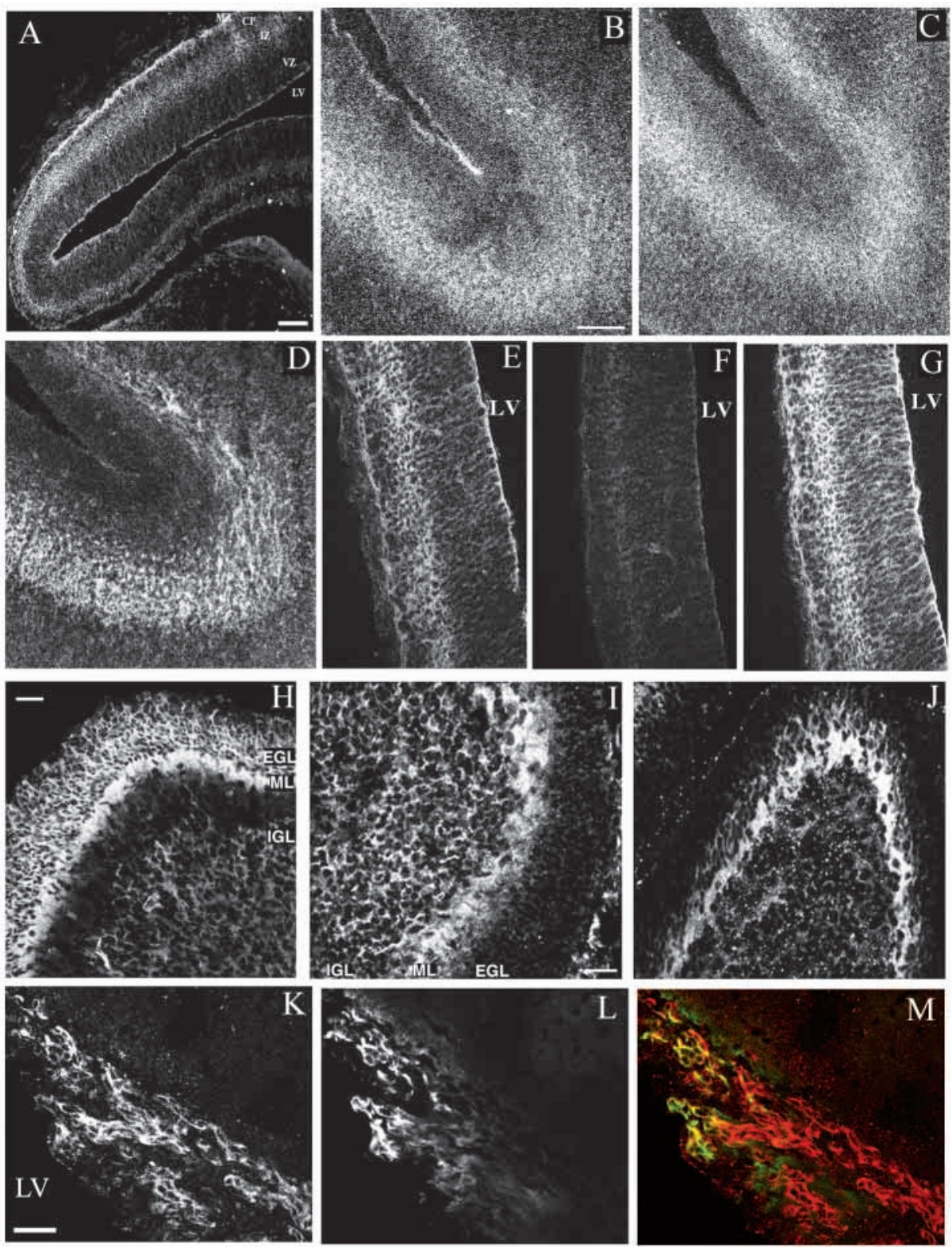

These data in conjunction with the immunoprecipitation data (Fig. 1) suggest that both neurofascin and L1 in the embryonic brain intermediate zone are phosphorylated at the FIGQY tyrosine. The complexity of the tissue and the overlapping expression of multiple ankyrins made it difficult to draw firm conclusions about the relative distributions of FIGQY phosphorylation and ankyrin (data not shown).

As a control for antibody specificity, serial sections of embryonic rat brain (E15) were labeled with phospho-FIGQY polyclonal antibody that had been pre-incubated with either a fivefold molar excess of tyrosine phosphorylated nFIGQY peptide (Fig. 7F), a fivefold molar excess of tyrosine phosphorylated angiotensin II peptide (Fig. 7G), or in the absence of peptide (Fig. 7E). The nFIGQY peptide eliminated the phospho-FIGQY signal, while the tyrosine phosphorylated angiotensin peptide did not. These results provide further evidence for the specificity of the phospho-FIGQY polyclonal antibody for the tyrosine-phosphorylated FIGQY sequence of L1 CAMs as examined by immunofluorescence.
Granule cells in the neonatal cerebellum migrate from their site of proliferation in the external germinal layer (EGL), to their final destination, the internal granule cell layer (IGL). During migration, granule cells extend axons in the molecular layer (ML) (Hatten, 1999). Sections of neonatal cerebellum labeled with the phospho-FIGQY polyclonal antibody revealed the presence of FIGQY-phosphorylated L1 CAMs in the migratory and pre-migratory granule cells of the external germinal layer, and in elongating granule cell axons of the molecular layer (Fig. 7H). FIGQY phosphorylation was less intense in the internal granule cell layer containing postmigratory granule cells and granule cells nearing the end of the migratory pathway. This signal was completely eliminated by pre-incubation of the antibody with the tyrosine phosphorylated nFIGQY peptide (data not shown). The phospho-FIGQY polyclonal antibody label co-localized with the expression of neuron-specific $\beta$-tubulin but not with the glial marker GFAP (S.M.J. and V.B., unpublished) suggesting that the cerebellar FIGQY-phosphorylated L1 CAM is 
neuronal and is not restricted to sites of neuron-glia contact. The distribution of FIGQY-phosphotyrosine label overlaps with the expression patterns of both neurofascin and L1 (Fig. $7 \mathrm{I}, \mathrm{J}$, respectively) in the molecular layer and the internal granule cell layer, supporting the immunoprecipitation data (see above) demonstrating that both neurofascin and L1 are phosphorylated at their FIGQY-tyrosine residues in neonatal cerebellum. Expression of both L1 CAMs is greatly reduced in the external germinal layer. Phosphorylation of the FIGQY tyrosine was not detected in the adult cerebellum (data not shown) indicating the transient and developmental nature of this phosphorylation event.

In adult rats, cells from the subventricular zone of the lateral ventricle migrate to the olfactory bulb along the rostral migratory stream (Lois and Alvarez-Buylla, 1994; Lois et al., 1996). The phospho-FIGQY polyclonal antibody labels cells in this region of continued neurogenesis and neuronal migration (Fig. 7K). The rostral migratory stream was identified based on the location and morphology of cells labeled with the phospho-FIGQY polyclonal antibody, and the overlap between the phospho-FIGQY signal with neuronspecific $\beta$-tubulin in the subventricular zone (Fig. 7L,M) (Rousselot et al., 1995), Moreover, the phospho-FIGQY signal overlaps with that of doublecortin (data not shown), which is a marker of migrating neurons that labels cells in the rostral migratory stream (Gleeson et al., 1999). The phosphoFIGQY signal was completely displaced by the tyrosine phosphorylated nFIGQY peptide (data not shown).

\section{DISCUSSION}

This study provides the first physiological insight, in both Drosophila and vertebrates, into the cellular localization of a functionally important phosphorylation event in a major class of adhesion molecules. L1-type cell adhesion molecules phosphorylated at the FIGQY tyrosine are localized to specialized sites of cell-cell contact, including paranodes of adult sciatic nerve, the neuromuscular junction of adult rats and Drosophila embyros, muscle-tendon junctions of Drosophila, and adherens junctions of developing epithelial cells of rat and Drosophila. In C. elegans, FIGQY-phosphorylated LAD-1 also is localized to adherens junctions of epithelial tissues and sites of body wall-muscle attachment (Chen et al., 2001). In addition, FIGQY-phosphorylated neurofascin and L1 are abundantly expressed in regions of neuronal migration and axon extension in the vertebrate central nervous system, including the embryonic cortex, the neonatal cerebellum and the adult rostral migratory stream. These findings establish that FIGQY-tyrosine phosphorylation of L1-type family members first characterized in cultured neuroblastoma cells (Garver et al., 1997), also occurs under physiological conditions and is evolutionarily conserved between flies, nematodes and mammals.

In cultured cells, phosphorylation of the FIGQY tyrosine of neurofascin decreases neurofascin-ankyrin interactions (Garver et al., 1997; Tuvia et al., 1997). If FIGQYphosphorylation performs a similar role under physiological conditions, then discrete, well-defined regions of ankyrin expression might remain distinct from regions containing FIGQY-phosphorylated L1-type adhesion molecules.
Moreover, ankyrin may colocalize with L1-type adhesion molecules not phosphorylated at the FIGQY tyrosine. This is precisely what we observe at the neuromuscular junction and sciatic nerve nodes of Ranvier. At the neuromuscular junction, ankyrin is confined to the depths of junctional folds and FIGQY phosphorylation to the crests of these folds, while at nodes of Ranvier clustered ankyrin G colocalizes with neurofascin and $\mathrm{NrCAM}$ that are not phosphorylated at the FIGQY tyrosine. Together, these results suggest that one physiological function of FIGQY phosphorylation is to regulate the interaction between L1 CAMs and ankyrin establishing ankyrin-containing and/or ankyrin-free microdomains. Through this mechanism FIGQY phosphorylation may play a role in morphogenesis of the node of Ranvier. Premyelinated axons contain uniformly distributed FIGQY-phosphorylated L1 CAMs (S.M.J. and V.B., unpublished), possibly localized in vesicles, which are subsequently targeted to specific domains in the plasma membrane. Localized dephosphorylation of neurofascin or $\mathrm{NrCAM}$ by a receptor tyrosine phosphatase could initiate recruitment of ankyrin $\mathrm{G}$, which could, in turn, recruit voltagegated $\mathrm{Na}^{+}$channels, which are dependent on ankyrin for restriction to axon initial segments (Zhou et al., 1998). Voltagegated $\mathrm{Na}^{+}$channels associate with RPTP- $\beta$ protein tyrosine phosphatase (Ratcliffe et al., 2000), and could participate in their own assembly and/or maintenance at the nodal axon segment. In support of such a model, examination of the developing sciatic nerve has revealed early clusters of neurofascin lacking ankyrin-G, followed by co-clustering of neurofascin and ankyrin $\mathrm{G}$, and finally by recruitment of voltage-gated $\mathrm{Na}^{+}$channels (Lambert et al., 1997).

In cultured cells, FIGQY phosphorylation of neurofascin also decreases neurofascin-mediated intercellular adhesion (Tuvia et al., 1997). A similar role for FIGQY phosphorylation might be important physiologically in cells undergoing migration or other forms of motility such as neurite extension. The combination of decreased intercellular adhesion and the destabilization of adhesion molecule-cytoskeletal linkages could be necessary for cell motility. The prominence of FIGQY phosphorylation in regions of neuroblast migration and axon extension is consistent with this hypothesis.

Spatial segregation between FIGQY phosphorylation and ankyrin expression (Chen et al., 2001) and the remarkably focussed distribution of FIGQY phosphorylation compared to total L1-type adhesion molecule distribution, particularly at adherens junctions, also suggests that FIGQY-phosphorylated L1-type adhesion molecules participate in an ankyrinindependent signaling/structural pathway. Key components of a phospho-FIGQY L1 CAM pathway including ligands, protein kinase(s) and protein phosphatase(s) remain to be elucidated. However, an adaptor protein that binds specifically to FIGQY-phosphorylated neurofascin has recently been identified as doublecortin (K.K. and V.B., unpublished). Doublecortin is involved in neuronal migration and is mutated in human neuronal migration disorders (des Portes et al., 1998; Gleeson et al., 1998; Sossey-Alaoui et al., 1998; Francis et al., 1999; Gleeson et al., 1999) suggesting the potential clinical importance of FIGQY tyrosine phosphorylation. Whether other phospho-FIGQY adaptors exist in non-neuronal tissues (e.g. adherens junctions) remains to be determined. The conservation of FIGQY phosphorylation between vertebrates, 
Drosophila and C. elegans at adherens junctions suggests a fundamentally important role for FIGQY phosphorylation in adhesion molecule function at these sites. In vertebrates at least, this role is transient during development consistent with an active signaling function rather than a more passive structural role.

Other specialized sites of cell-cell contact containing FIGQY-phosphorylation include paranodes of adult sciatic nerve and the neuromuscular junction. In adult vertebrate sciatic nerves, the paranodal phospho-FIGQY-containing protein is presumably neurofascin (Davis et al., 1996; Tait et al., 2000). Although we could not distinguish axonal from glial labeling at the light level, paranodal phospho-FIGQY probably represents the $155 \mathrm{kDa}$ neurofascin isoform recently identified as a glial component of the septate-like junction anchoring axons to myelinating glia (Tait et al., 2000; Trapp and Kidd, 2000). In Drosophila, although neuroglian expression has been demonstrated in muscle cells (Hortsch et al., 1990), the present findings provide the first evidence for the presence of an L1type family member at the neuromuscular junction. FIGQYphosphorylation of neuroglian was seen in the embryonic but not the larval neuromuscular junction, while the adult vertebrate neuromuscular junction contained FIGQY phosphorylation. Thus, the specific function of junctional FIGQY phosphorylation is different in flies and vertebrates. The vertebrate L1 CAM at the neuromuscular junction may represent a splice variant not recognized by our antibodies or, by elimination, could be CHL1, the only vertebrate L1 CAM not examined in the present study. CHL1 diverges in the FIGQY (FIGAY in the case of CHL1) region and reactivity with the phospho-FIGQY polyclonal antibody remains to be evaluated. Similar reasoning can be applied to regions of the nervous system containing FIGQY phosphorylation that did not overlap with examined L1 CAMs.

The protein kinase(s) that phosphorylates the FIGQY tyrosine is unknown. FIGQY phosphorylation of LAD-1 in C. elegans epithelial tissues depends on the fibroblast growth factor receptor (FGFR) but not the epidermal growth factor receptor (EGFR) and ROR kinase (Chen et al., 2001). FIGQY phosphorylation in FGFR mutants was rescued by gain of function Ras indicating that a protein kinase downstream of the FGFR directly phosphorylates LAD-1 (Chen et al., 2001). The tyrosine kinase Src did not phosphorylate a bacteriallyexpressed neurofascin cytoplasmic domain construct (S.M.J. and V.B., unpublished), suggesting that Src and possibly related protein tyrosine kinases do not phosphorylate the FIGQY tyrosine directly. The $C$. elegans ROR receptor tyrosine kinase is homologous to mammalian muscle-specific kinase (MuSK) found at the neuromuscular junction (Valenzuela et al., 1995), arguing against the hypothesis that MuSK phosphorylates the L1 CAM localized to postsynaptic folds of the neuromuscular junction.

The presence of FIGQY-phosphotyrosine label in diverse but highly specific sites and in multiple L1 family members suggests that the signaling pathway that regulates this phosphorylation event is of general importance to the normal functioning of the L1-type adhesion molecule family. Elucidation of other components of the FIGQY-signaling pathway may be accessible using genetic approaches in Drosophila and C. elegans. The L1-type adhesion molecules share three other conserved tyrosine residues in their cytoplasmic domains that may function as targets for protein tyrosine kinase(s). Concerted regulation of the phosphorylation of these tyrosines could allow for a complex role in cell signaling. It also is worth noting that the present work provides a conceptually straightforward approach using antibodies to localize proteins phosphorylated at specific sites that could be used to investigate the physiological occurrence of specific signaling events in other cell adhesion molecules such as integrins and cadherins.

The authors thank Lydia Davis for generating the ankyrin-G monoclonal antibody, Dr C. Laganaur and Dr D. Felsenfeld for the L1 polyclonal antibody, Dr M. Hortsch for the neuroglian antibody, Dr C. Goodman for the FasII antibody, Dr J. Bloor and Dr N. Brown for the PS alpha II antibody, Drs R. Wharton and D. Kiehart for helpful discussions and technical assistance with Drosophila, Dr L. Cantley for use of scansite.bicmid.harvard.edu, and Drs. L. Chen and D. Felsenfeld for helpful discussions regarding the manuscript.

\section{REFERENCES}

Bar, I., Lambert de Rouvroit, C. and Goffinet, A. M. (2000). The reelinsignaling pathway and mouse cortical development. In Mouse Brain Development (ed. A. M. Goffinet and P. Rakic), pp. 255-276. Berlin: Springer-Verlag.

Behrens, J. (1999). Cadherins and catenins: role in signal transduction and tumor progression. Cancer Metastasis Rev. 18, 15-30.

Bieber, A. J., Snow, P. M., Hortsch, M., Patel, N. H., Jacobs, J. R., Traquina, Z. R., Schilling, J. and Goodman, C. S. (1989). Drosophila neuroglian: a member of the immunoglobulin superfamily with extensive homology to the vertebrate neural adhesion molecule L1. Cell 59, 447-460.

Bogeart, T., Brown, N. and Wilcox, M. (1987). The Drosophila PS2 antigen is an invertebrate integrin that, like the fibronectin receptor, becomes localized to muscle attachments. Cell 51, 929-940.

Broadie, K. S. (1999). Development of electrical properties and synaptic transmission at the embryonic neuromuscular junction. In Neuromuscular Junctions in Drosophila (ed. R. J. Bradley, R. A. Harris and P. Jenner), pp. 45-67. London: Academic Press.

Chen, L., Ong, B. and Bennett, V. (2001). LAD-1, the Caenorhabditis elegans L1 CAM homologue, participates in embryonic and gonadal morphogenesis and is a substrate for fibroblast growth factor receptor pathway-dependent phosphotyrosine-based signaling. J. Cell Biol. 154, 841855.

Chung, W. W., Lagenaur, C. F., Yan, Y. M and Lund, J. S. (1991). Developmental expression of neural cell adhesion molecules in the mouse neocortex and ofactory bulb. J. Comp. Neurol. 314, 290-305.

Cohen, N. R., Taylor, J. S., Scott, L. B., Guillery, R. W., Soriano, P. and Furley, A. J. (1998). Errors in corticospinal axon guidance in mice lacking the neural cell adhesion molecule L1. Curr. Biol. 8, 26-33.

Cox, R. T., Kirkpatrick, C. and Peifer, M. (1996). Armadillo is required for adherens junction assembly, cell polarity, and morphogenesis during Drosophila embryogenesis. J. Cell Biol. 134, 133-148.

Davis, J. Q., Lambert, S. and Bennett, V. (1996). Molecular composition of the node of Ranvier: identification of ankyrin-binding cell adhesion molecules neurofascin (mucin+/third FNIII domain-) and NrCAM at nodal axon segments. J. Cell Biol. 135, 1355-1367.

Davis, J. Q., McLaughlin, T. and Bennett, V. (1993). Ankyrin-binding proteins related to nervous system cell adhesion molecules: candidates to provide transmembrane and intercellular connections in adult brain. J. Cell Biol. 121, 121-133.

Demyanenko, G. P., Tsai, A. Y. and Maness, P. F. (1999). Abnormalities in neuronal process extension, hippocampal development, and the ventricular system of L1 knockout mice. J. Neurosci. 19, 4907-4920.

Desai, C. J., Popova, E. and Zinn, K. (1994). A Drosophila receptor tyrosine phosphatase expressed in the embryonic CNS and lrval optic lobes is a member of the set of proteins bearing the HRP carbohydrate epitope. $J$. Neurosci. 14, 7272-7283.

des Portes, V., Pinard, J. M., Billuart, P., Vinet, M. C., Koulakoff, A., Carrie, A., Gelot, A., Dupuis, E., Motte, J., Berwald-Netter, Y. et al. 
(1998). A novel CNS gene required for neuronal migration and involved in X-Linked Subcortical Laminar Heterotopia and Lissencephaly Syndrome. Cell 92, 51-61.

Flucher, B. E. and Daniels, M. P. (1989). Distribution of $\mathrm{Na}+$ channels and ankyrin in neuromuscular junctions is complementary to that of acetylcholine receptors and the $43 \mathrm{kd}$ protein. Neuron. 3, 163-175.

Francis, F., Koulakoff, A., Boucher, D., Chafey, P., Schaar, B., Vinet, M.C., Friocourt, G., McDonnell, N., Reiner, O., Kahn, A. et al. (1999). Doublecortin is a developmentally regulated, microtubule-associated protein expressed in migrating and differentiating neurons. Neuron 23, 247-256.

Fransen, E., Van Camp, G., Vits, L. and Willems, P. J. (1997). L1-associated diseases: clinical geneticists divide, molecular geneticists unite. Hum. Mol. Genet. 6, 1625-1632.

Garcia-Alonso, L., Romani, S. and Jimenez, F. (2000). The EGF and FGF receptors mediate neuroglian function to control growth cone decisions during sensory axon guidance in Drosophila. Neuron 28, 741-752.

Garver, T. D., Ren, Q., Tuvia, S. and Bennett, V. (1997). Tyrosine phosphorylation at a site highly conserved in the L1 family of cell adhesion molecules abolishes ankyrin binding and increases lateral mobility of neurofascin. J. Cell Biol. 137, 703-714.

Gleeson, J. G., Allen K. M., Fox, J. W., Lamperti, E. D., Berkovic, S., Scheffer, I., Cooper, E. C., Dobyns, W. B., Minnerath, S. R., Ross, M. E. and Walsh C. A. (1998). Doublecortin, a brain-specific gene mutated in human x-linked lissencephaly and double cortex syndrome, encodes a putative signaling protein. Cell 92, 63-72.

Gleeson, J. G., Lin P. T., Flanagan, L. A. and Walsh C. A. (1999). Doublecortin is a microtubule-associated protein and is expressed widely by migrating neurons. Neuron 23, 257-271.

Hall, S. G. and Bieber, A. J. (1997). Mutations in the Drosophila Neuroglian cell adhesion molecule affect motor neuron pathfinding and peripheral nervous system patterning. J. Neurobiol. 32, 325-340.

Hatten, M. E. (1999). Central nervous system neuronal migration. Annu. Rev. Neurosci. 22, 511-539.

Holm, J., Hillenbrand, R., Steuber, V., Bartsch, U., Moos, M., Lubbert, H., Montag, D. and Schachner, M. (1996). Structural features of a close homologue of L1 (CHL1) in the mouse: a new member of the L1 family of neural recognition molecules. Eur. J. Neurosci. 8, 1613-1629.

Honig, M. G., Petersen, G. G., Rutishauser, U. S. and Camilli, S. J. (1998). In vitro studies of growth cone behavior support a role for fasciculation mediated by cell adhesion molecules in sensory axon guidance during development. Dev. Biol. 204, 317-326.

Hortsch, M. (2000). Structural and functional evolution of the L1 family: are four adhesion molecules better than one?. Mol. Cell Neurosci. 15, 1-10.

Hortsch, M. (1996). The L1 family of neural cell adhesion molecules: old proteins performing new tricks. Neuron. 17, 587-593.

Hortsch, M., Bieber, A. J., Patel, N. H. and Goodman, C. S. (1990). Differential splicing generates a nervous system-specific form of Drosophila neuroglian. Neuron. 4, 697-709.

Ignelzi, M. A., Jr, Miller, D. R., Soriano, P. and Maness, P. F. (1994). Impaired neurite outgrowth of src-minus cerebellar neurons on the cell adhesion molecule L1. Neuron 12, 873-884.

Jones, J. L. and Walker, R. A. (1999). Integrins: a role as cell signalling molecules. Mol. Pathol. 52, 208-213.

Kadmon, G., Montgomery, A. M. and Altevogt, P. (1998). L1 makes immunological progress by expanding its relations. Dev Immunol. 6, 205-213.

Kamiguchi, H., Hlavin, M. L., Yamasaki, M. and Lemmon, V. (1998). Adhesion molecules and inherited diseases of the human nervous system. Annu. Rev. Neurosci. 21, 97-125.

Kenwrick, S., Watkins, A. and Angelis, E. D. (2000). Neural cell recognition molecule L1: relating biological complexity to human disease mutations. Hum. Mol. Genet. 9, 879-886.

Kordeli, E., Davis, J., Trapp, B. and Bennett, V. (1990). An isoform of ankyrin is localized at nodes of Ranvier in myelinated axons of central and peripheral nerves. J. Cell Biol. 110, 1341-1352.

Kordeli, E., Lambert, S. and Bennett, V. (1995). Ankyrin G: A new ankyrin gene with neural-specific isoforms localized at the axonal initial segment and node of ranvier. J. Biol. Chem. 270, 2352-2359.

Kordeli, E., Ludosky, M. A., Deprette, C., Frappier, T. and Cartaud, J. (1998). AnkyrinG is associated with the postsynaptic membrane and the sarcoplasmic reticulum in the skeletal muscle fiber. J. Cell Sci. 111, 21972207.

Kramarcy, N. R. and Sealock, R. (2000). Syntrophin isoforms at the neuromuscular junction: developmental time course and differential localization. Mol. Cell. Neurosci. 15, 262-274.
Lambert, S., Davis, J. Q. and Bennett, V. (1997). Morphogenesis of the node of Ranvier: co-clusters of ankyrin and ankyrin-binding integral proteins define early developmental intermediates. J. Neurosci. 17, 7025-7036.

Lefevre, G. and Watkins, W. (1986). The question of the total gene number in Drosophila melanogaster. Genetics 113, 869-895.

Lemmon, V. and McLoon, S. C. (1986). The appearance of an L1-like molecule in the chick primary pathway. J. Neurosci. 6, 2987-2994.

Liljelund, P., Ghosh, P. and Van Den Pol, A. L. (1994) Expression of the neural axon adhesioin molecule L1 in the developing and adult rat brain. $J$. Biol. Chem. 269, 32886-32895.

Lindner, J., Rathjen, F. G. and Schachner, M. (1983). L1 mono- and polyclonal antibodies modify cell migration in early postnatal mouse cerebellum. Nature 305, 427-430.

Lois, C. and Alvarez-Buylla, A. (1994). Long-distance migration in the adult mammalian brain. Science 264, 1145-1148.

Lois, C., Garcia-Verdugo, J. M. and Alvarez-Buylla, A. (1996). Chain migration of neuronal precursors. Science 271, 978-981.

Martin-Bermudo, M. D. and Brown, N. H. (1996). Intracellular signals direct integrin localization to sites of function in embryonic muscles. J. Cell Biol. 134, 217-226.

Nolte, C., Moos, M. and Schachner, M. (1999). Immunolocalization of the neural cell adhesion molecule L1 in epithelia of rodents. Cell Tissue Res. 298, 261-273.

Ratcliffe, C. F., Qu, Y., McCormick, K. A., Tibbs, V. C., Dixon, J. E., Scheuer, T. and Catterall, W. A. (2000). A sodium channel signaling complex: modulation by associated receptor protein tyrosine phosphatase beta. Nat. Neurosci. 3, 437-444.

Rathjen, F. G., Wolff, J. M., Frank, R., Bonhoeffer, F. and Rutishauser, U. (1987). Membrane glycoproteins involved in neurite fasciculation. J. Cell Biol. 104, 343-353.

Rousselot, P., Lois, C. and Alvarez-Buylla, A. (1995). Embryonic (PSA) NCAM reveals chains of migrating neuroblasts between the lateral ventricle and the olfactory bulb of adult mice. J. Comp. Neurol. 351, 51-61.

Saffell, J. L., Williams, E. J., Mason, I. J., Walsh, F. S. and Doherty, P. (1997). Expression of a dominant negative FGF receptor inhibits axonal growth and FGF receptor phosphorylation stimulated by CAMs. Neuron. 18, 231-242.

Schaefer, A. W., Kamiguchi, H., Wong, E. V., Beach, C. M., Landreth, G. and Lemmon, V. (1999). Activation of the MAPK signal cascade by the neural cell adhesion molecule L1 requires L1 internalization. J. Biol. Chem. 274, 37965-37973.

Schmid, R. S., Pruitt, W. M. and Maness, P. F. (2000). A MAP kinasesignaling pathway mediates neurite outgrowth on L1 and requires Srcdependent endocytosis. J. Neurosci. 20, 4177-4188.

Schuster, C. M., Davis, G. W., Fetter, R. D. and Goodman, C. S. (1996). Genetic dissection of structural and functional components of synaptic plasticity. I. Fasciclin II controls synaptic stabilization and growth. Neuron 17, 641-654.

Seeger, M., Tear, G., Ferres-Marco, D. and Goodman, C. S. (1993). Mutations affecting growth cone guidance in Drosophila: genes necessary for guidance toward or away from the midline. Neuron 10, 409-426.

Seilheimer, B. and Schachner, M. (1988). Studies of adhesion molecules mediating interactions between cells of peripheral nervous system indicate a major role for L1 in mediating sensory neuron growth on Schwann cells in culture. J. Cell Biol. 107, 341-351.

Sossey-Alaoui, K., Hartung, A. J., Guerrini, R., Manchester, D. K., Posar, A., Puche-Mira, A., Andermann, E., Dobyns, W. B. and Srivastava, A. K. (1998). Human doublecortin (DCX) and the homologous gene in mouse encode a putative calcium-dependent signaling protein which is mutated in human X-linked neuronal migration defects. Human Mol. Genet. 7, 1327-1332.

Stoeckli, E. T. and Landmesser, L. T. (1995) Axonin-1, Nr-CAM, and NgCAM play different roles in the in vivo guidance of chick commissural neurons. Neuron 14, 1165-1179.

Tait, S., Gunn-Moore, F., Collinson, J. M., Huang, J., Lubetzki, C., Pedraza, L., Sherman, D. L., Colman, D. R. and Brophy, P. J. (2000). An oligodendrocyte cell adhesion molecule at the site of assembly of the paranodal axo-glial junction. J. Cell Biol. 150, 657-666.

Tepass, U. and Hartenstein, V. (1994). The development of cellular junctions in the Drosophila embryo. Dev. Biol. 161, 563-596.

Trapp, B. D. and Kidd, G. J. (2000). Axo-glial septate junctions: The maestro of nodal formation and myelination? J. Cell Biol. 150, F97-F99.

Tuvia, S., Garver, T. D. and Bennett, V. (1997). The phosphorylation state of the FIGQY tyrosine of neurofascin determines ankyrin-binding activity and patterns of cell segregation. Proc. Natl. Acad. Sci. USA 94, $12957-$ 12962. 
Valenzuela, D. M., Stitt, T. N., DiStefano, P. S., Rojas, E., Mattsson, K., Compton, D. L., Nunez, L., Park, J. S., Stark, J. L., Gies, D. R. et al. (1995). Receptor tyrosine kinase specific for the skeletal muscle lineage: expression in embryonic muscle, at the neuromuscular junction, and after injury. Neuron 15, 573-584.

Van Vactor, D., Sink, H., Fambrough, D., Tsoo, R. and Goodman, C. S. (1993). Genes that control neuromuscular specificity in Drosophila. Cell 73, $1137-1153$

Walsh, F. S. and Doherty, P. (1997). Neural cell adhesion molecules of the immunoglobulin superfamily: role in axon growth and guidance. Annu. Rev. Cell Dev. Biol. 13, 425-456.

Wang, B., Williams, H., Du, J., Terrett, J. and Kenwrick, S. (1998), Alternative splicing of human $\mathrm{NrCAM}$ in neural and nonneural tissues. Mol. Cell. Neurosci. 10, 287-295.
Wood, S. J. and Slater, C. R. (1998). $\beta$-Spectrin is colocalized with both voltage-gated sodium channels and ankyrinG at the adult rat neuromuscular junction. J. Cell Biol. 140, 675-684.

Zhang, X., Davis, J. Q., Carpenter, S. and Bennett, V. (1998). Structural requirements for association of neurofascin with ankyrin. J. Biol. Chem. 273, 30785-30794.

Zhou, D., Lambert, S., Malen, P. L., Carpenter, S., Boland, L. M. and Bennett, V. (1998). Ankyrin G is required for clustering of voltage-gated $\mathrm{Na}$ channels at axon initial segments and for normal action potential firing. J. Cell Biol. 143, 1295-1304.

Zisch, A. H., Stallcup, W. B., Chong, L. D., Dahlin-Huppe, K., Voshol, J., Schachner, M. and Pasquale, E. B. (1997). Tyrosine phosphorylation of L1 family adhesion molecules: implication of the Eph kinase Cek5. $J$ Neurosci Res. 47, 655-665. 